DOI: $10.15393 /$ j10.art.2019.4061

УДК 070

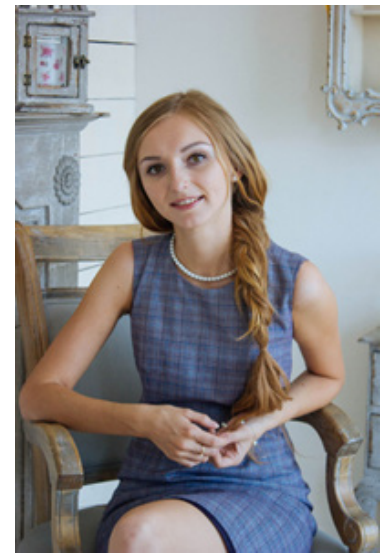

Анастасия Андреевна Прощенко

(Москва, Российская Федерация)

anastessa@list.ru

\title{
«Достоевец» Суворин: от противоборства к сбдижению*
}

Аннотация. В данной статье рассмотрена эволюция взаимоотношений литераторов $Ф$. М. Достоевского и А. С. Суворина. Особое внимание уделено изменению взглядов издателя «Нового времени» на творчество и личность Ф. М. Достоевского: их взаимоотношения прошли непростой путь от идейно-политического противостояния до взаимного уважения и дружбы. Влияние А. С. Суворина на творческую деятельность и наследие писателя весьма обширно: оно вовсе не исчерпывается известными воспоминаниями из дневника медиамагната и выходит далеко за пределы его газетных фельетонов. Издатель «Нового времени» не только неизменно поддерживал Достоевского на страницах своей газеты, но и принимал активное участие в сооружении памятника писателю, создании школы им. Достоевского в Старой Руссе, подготовке и публикации Полного собрания сочинений. А. С. Суворин поддерживал также и близких Ф. М. Достоевского после его смерти, а в 1899 г. впервые поставил на сцене «Преступление и наказание». Достоевский очень ценил А. С. Суворина и прислушивался к его мнению: в полемике с «Незнакомцем» родилось множество идей для будущих великих произведений.

Ключевые слова: Ф. М. Достоевский, А. С. Суворин, газета «Новое время», история взаимоотношений, журналистика, окружение Достоевского

Об авторе: Прощенко Анастасия Андреевна - преподаватель-исследователь, лаборант факультета журналистики, Московский государственный университет им. М. В. Ломоносова (125009, Российская Федерация, г. Москва, ул. Моховая, д. 9, стр. 1)

Дата поступления: 15.03.2019

Дата публикации: 30.06 .2019

Для цитирования: Прощенко А. А. «Достоевец» Суворин: от противоборства к сближению // Неизвестный Достоевский. — 2019. — № 2. — C. 149-170. DOI: 10.15393/j10.art.2019.4061 
$\mathrm{H}$ есмотря на то, что А. С. Суворин был младше Ф. М. Достоевского на 13 лет, его по праву можно назвать искренним другом и защитником писателя, сделавшим все возможное для увековечивания памяти о нем.

Считается, что знакомство литераторов произошло в 1875 г., однако при подробном изучении дневника Суворина становится очевидным, что их заочное знакомство произошло значительно раньше - около 1863 г. Вспоминая в 1899 г. о начале своего жизненного и творческого пути, А. С. Суворин писал: «Участвовал в “Модном магазине” <...> “Отечественных Записках”, “Времени” Достоевского (повесть “Аленка” была принята Ф. М. Достоевским, набрана там но “Время” было запрещено и повесть явилась потом в “Отечественных Записках")...»"

8 августа 1864 г. в «Русском инвалиде», где молодой Суворин работал журнальным обозревателем и вел раздел «Журнальные и библиографические заметки», вышел его отрицательный отзыв на журнал «Эпоха». Автор рецензии подписывался псевдонимом «А. И-н» ${ }^{2}$, давая характеристику происходящему в современной периодике, писал о журналах братьев Достоевских:

«Хотелось бы мне поговорить об “Эпохе”, но умер ее редактор, и перед свежею могилою блекнут все мои замыслы. Г. Достоевскому (покойному) нельзя поставить в заслугу “Эпохи”, но можно поставить в заслугу “Время”, которое издавалось разнообразно, можно поставить в заслугу переводы из Гете и Шиллера. Увидим, как пойдет “Эпоха" дальше, и будет ли она попрежнему печатать такие удивительные (во всех отношениях) полемические статьи, каковыми наполнена последняя книжка, или смирится перед сильным, действительно остроумным противником и займется делом. А не худо бы полемику в сторону: ведь слишком уж простодушна»³.

По-видимому, Суворин имел в виду полемику между Ф. М. Достоевским и М. Е. Салтыковым-Щедриным и, в первую очередь, опубликованную в «Эпохе» за месяц до этого статью Достоевского «Господин Щедрин, или Раскол в нигилистах».

Еще через три года вышла рецензия Суворина на вторую часть «Преступления и наказания», в которой «А. И-н» указывает на связь событий романа с процессом студента А. М. Данилова ${ }^{4}$ :

«Странное дело: незадолго до появления “Преступления и наказания” в Москве совершено убийство, почти такое же, какое описывает г. Достоевский, и также молодым образованным человеком»5.

Суворин проводит мысль, что Раскольников «вовсе не тип, не воплощение какого-нибудь направления, какого-нибудь склада мыслей, усвоенных множеством». Он пишет, что «общей черты здесь схватить невозможно, потому что тут многое зависит от индивидуальности, от обстоятельств» ${ }^{6}$. 
Будущий издатель «Нового времени» молод и еще не осознает той значимости, которую обретет «идея» Раскольникова в скором будущем, каким пророческим окажется роман Достоевского. С возрастом Суворин не только переосмыслит это произведение, но и поставит его на сцене собственного театра. Пока же 33-летний фельетонист понимает «Преступление и наказание» весьма поверхностно:

«В романе много страниц прекрасных, вполне художественных, но в нем немало также страниц слабых, недостаточно выясненных. Завязка крайне запутана и обременена лишними подробностями, приклеенными или ради эффекта, или совсем неизвестно для чего»?

За последующие шесть лет (1867-1873) Суворин и Достоевский не упоминают друг о друге ни в периодике, ни в личных тетрадях. Интересно, что в 1873 г. в «Новом времени» вышло три весьма противоречивых критических отзыва о творчестве Достоевского, подписанных псевдонимом «А. С.» ${ }^{8}$. Сoгласно словарю псевдонимов русских писателей, ученых и общественных деятелей [Масанов: 458], эти тексты принадлежат перу А. С. Суворина. Однако исследователь Л. Е. Азарина доказывает, что это мнение ошибочно [Азарина, 2008]. Суворин собирал вырезки из газет и журналов со своими статьями - благодаря этому исследователи могут сегодня идентифицировать анонимные или подписанные псевдонимами публикации Суворина 9 . Однако в суворинском архиве нет вырезок, содержащих данные фельетоны, а сам писатель нигде не упоминает о своем сотрудничестве в газете «Новое время» до ее приобретения в 1876 г. Библиограф С. И. Пономарев, составляя перечень литературно-критических статей Суворина к 50-летию его творческой деятельности ${ }^{10}$, включил три указанных фельетона в число работ, принадлежащих перу Суворина. Сам же Суворин, просматривая библиографию Пономарева, под списком публикаций в «Новом времени» 1873 г. подписал: «Нет, не мое» ${ }^{11}$, - и этому опровержению стоит верить.

Однако именно в 1873 г. между Сувориным и Достоевским завязалась полемика, которая впоследствии переросла в дружбу и породила множество «мысленных диалогов» в дневниковых записях и заметках обоих писателей. В 1873 г. Суворин работал фельетонистом в «Санкт-Петербургских ведомостях», а Достоевский - редактором «Гражданина», разделом которого являлся «Дневник писателя». В выпуске газеты от 25 февраля 1873 г. Суворин («Незнакомец») публикует критический отзыв о статье Достоевского «Среда» ${ }^{12}$, в которой автор «Записок из Мертвого дома» сетует на большое количество оправдательных приговоров, считая, что наказание нередко помогает преступнику осознать свою вину и очиститься через страдания на каторге. Суворину-либералу эта мысль не близка: в своем фельетоне он пишет, что «автор "Неточки Незвановой" имел гораздо большее значение в русской литературе и представил бы в ней весьма крупное явление, если 6 не имел несчастья попасть в “Мертвый дом”. Но уж видно такова судьба 
всех тех, которые попадают в мертвый дом “Гражданина”, что они начинают чувствовать влечение к бичеванию и очищению» ${ }^{13}$.

Так, критические отзывы Суворина имеют не столько личный, сколько «корпоративный» характер: от него, как от представителя «Санкт-Петербургских ведомостей», требовались некие «выпады» в сторону конкурентов - эту моду на острую газетную полемику диктовало время. В свою очередь Достоевский в июле того же года иронически прокомментировал в «Дневнике писателя» фельетон Незнакомца, споря с автором о том, стоил ли русский народ реформы 1861 г.:

«Я как раз прочел перед тем в одном фельетоне преоткровенное признание одного, уж конечно, умного человека по поводу вышедшей одной официального характера книги - именно что заниматься вопросом о том: полезна или не полезна была народу реформа? - есть в сущности вопрос праздный...» ${ }^{14}$.

Суворин утверждал, что «если мы до реформы в литературе и публицистике венчали лаврами и розами <..> мужиков, то ведь мы очень хорошо знаем, что венчали только вшивые головы... Но нужно было это тогда для подживления дела» ${ }^{15}$.

Достоевский в корне не согласен с этой идеей: для него, побывавшего на каторге, главное - человеческая личность и ее свобода. Автор «Записок из Мертвого дома» не может принять пренебрежительного тона Незнакомца по отношению к русскому народу:

«Признаюсь, эта слишком уже откровенная мысль, эта обнаженность ее, почти впервые обнаружившаяся с таким удовольствием, привела меня тогда в прелюбопытное настроение духа, и помню, я тогда заключил, что мы, ну например в “Гражданине” <..> не разделим ни за что второй части этой роковой мысли и твердо уверены, что вшивые головы все-таки были достойны реформы и даже совсем не ниже ее» (Д30; 21: 114).

Достоевский размышлял над фельетонами Суворина и наедине с самим собой. «Незнакомец» нередко фигурировал в записных тетрадях писателя, он спорил с ним, порой даже предполагая его ответы. Достоевский еще воспринимал Суворина как антагониста, однако, по наблюдению Г. Ф. Коган в комментариях к записным тетрадям 1874-1875 гг., в 1874 г. Достоевский даже предполагает публиковать фельетоны Незнакомца в «Гражданине».

Несмотря на это, в записных тетрадях 1875-1876 гг. Достоевский весьма суров по отношению к Суворину:

«Я васъ не считаю честнымъ титераторомб Г. Су-инб» ${ }^{16}$;

«Незнакомеиъ находится въ бальшивомъ положеніи, потому что вдругъ вообразиль себя почему-то геніемб, и главное одинб: никто ровно не помогаль ему въ этомъ. Теперь во всякомб фельетонп сльиится препротивненькая 
фальшь: [все] [\{онб\}] Хочет[в]\{ся\} говорить игриво $\{$ и просто $\}$, но [все] хочется также говорить нпчто чрезвычайно премудрое, до того премудрое что никому и въ голову не прійдетъ. Хочется подавлять[,] остроуміемъ. \{Смотр. фельетонъ Бирж. № 357.\} И вотъ къ удивленію нашему ни игривости невидно,

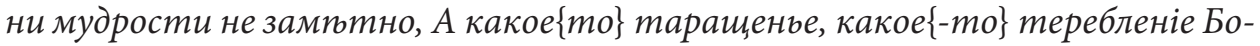
гомъ данной пориіи ума и таланта чтобъ раздать ихъ въ размпры Сухарев. бамни»»17.

На наш взгляд, едкость Достоевского может объясняться не только предполагаемой обидой на критические отклики, но и разногласиями во взглядах на политические и социальные темы. Как известно, Суворин начинал свой путь как либерал ${ }^{18}$, это претило Достоевскому:

«Я вамъ скажу, что вашъ либерализмь есть ремесло; или дурная привычка. Сама собою эта привычка не дурная, но у васъ она обратилась въ дурную.

Вы скажете что напротивъ не ремесло, а что вы были согриты чувствами и т. д. А я скажу что ничюмъ вы не были согрптыь, а просто за просто отправляливыгодную профессію, ичтовообщенамъдалекодонагрпвванія...»" ${ }^{19}$.

Суворина часто упрекали в продажности и «заигрывании с властью». Широко известна статья В. И. Ленина с красноречивым заголовком «Карьера», где «Новое время» называется «образцом продажных газет», а «либеральный журналист Суворин» - «лакеем», который «во время второго демократического подъема в России (конец 70-х годов XIX века) повернул к национализму, к шовинизму, к беспардонному лакейству перед власть имущими ${ }^{20}$. Однако если статья Ленина вышла только после смерти Суворина, то Достоевский в записных тетрадях сравнивал А. С. Суворина с Ф. В. Булгариным (пожалуй, самым скандальным представителем торгового направления в журналистике) еще в 1875 г.:

«Сравненіе Либеральнаго фельетона съ бывшимъ Булгаринскимъ ${ }^{1}$ : та же самая криокая опора сзади» $»^{21}$.

На наш взгляд, упреки Суворина в карьеризме и корыстолюбии не совсем справедливы. По словам Чехова, владелец «Товарищества "Новое время"» хорошо платил своим авторам. В письме И. Н. Крамскому 1885 г. и сам Суворин писал, что он «более пятидесяти тысяч рублей числит за должниками» и «ни разу с ними не судился»:

«...я никого не эксплуатировал, никого не жал, напротив, делал все, что может делать хороший хозяин относительно своих сотрудников и рабочих... Газета дает до 600 тысяч в год, а у меня кроме долгов ничего нет, то есть нет денег. Есть огромное дело, которое выросло до миллионного оборота, но я до сих пор не знал никакого развлечения, никаких наслаждений, кроме труда

\footnotetext{
${ }^{1}$ Вместо: либеральнаго Булгаринскимъ - было: Незнакомиа съ Булгаринымъ
} 
самого каторжного. Расчетлив я никогда не был, на деньги никогда не смотрел как на вещь, стоящую внимания» ${ }^{22}$.

Некоторые исследователи не доверяют словам этого письма, считая их лукавством, - но вряд ли Суворин стал бы лукавить в своем дневнике:

«Мне страшно подумать, что <...> я снова должен сидеть вечера дома и заниматься целые сутки газетой. Она взяла всю мою жизнь, дала много горечи, много удовольствий. Она держала меня в струе умственных интересов и дала мне значение и состояние, но все это ценою только каторжного труда, что я не жил, как все живут, теми удовольствиями и радостями, которые всех притягивают к жизни» ${ }^{23}$.

В мысленной полемике Достоевского с Сувориным рождаются многие идеи будущих великих романов. Так, в ноябре-декабре 1875 г. в Петербурге громко обсуждалось дело Овсянникова: крупный торговец мукой обвинялся в умышленном поджоге арендованной им паровой мельницы. Суд установил, что поджог был выгоден Овсянникову: купца приговорили к лишению всех прав состояния и ссылке на поселение в Сибирь, а его сообщников к каторжным работам на 8 и 9 лет. Достоевский внимательно следил за газетной полемикой по делу Овсянникова (он и сам упоминает об Овсянникове в октябрьском выпуске «Дневника писателя» за 1876 г. Д30; 23: 157), с интересом наблюдая и за реакцией Суворина на происходящее:

«Въ Биржевыхъ от 7о Воскресеніе въ фельетонпь Суворина ${ }^{24}$, смпшной парадоксъ объ Овсянниковп: Что еслибъ онб и не быль виновать въ поджогп, то все равно его за прежніе безнаказанные грпхи надо обвинить теперь 86 поджоги» ${ }^{25}$.

Достоевский согласен с тем, что Овсянников виновен, но его возмущает, что в подобных суждениях «меры нет». В том числе он отмечает фельетоны Суворина $^{26}$ против присяжного поверенного П. А. Потехина (который защищал Овсянникова на суде). В № 357 «Голоса» был опубликован ответ П. А. Потехина на выпады Суворина, в котором присяжный поверенный называет высказывания фельетониста «неправильными и оскорбительными толками». Достоевский помечает:

«Голосъ. 28 Декабр. № 357. Воскресеніе. Письмо Потпхина. (В. Ждать отвпьта Суворина)» 27.

В это время Достоевский прямо-таки беседует с будущим издателем «Нового времени» на страницах своих записных тетрадей:

«незнакомиу. Потому что нельзя себп позволять иныхъ выраженій (въ родю репутаціи Потюхина) и вы знаете почему.

- Почему? 
- Я вамъ скажу. Потому что всп мы обязаны быть людьми порядочными, а порядочный человпкъ такого отноченія къ другому человпку позволить себю не можеть. А если на случай и не захочется продолжать быть порядочнымъ человпкомъ (почему нибудь тяжело станетъ), то все же хоть видимо мьь должны воздержать себя, изъ уваженія къ порядочности, если только хотимъ принадлежать къ изивилизаціи. Не хотите - другое дюло. Тогда и дюлайте что хотите, но на такія желанія частныхъ тииь общество импеть полицію, которая и ограждаетъ его»²8.

Достоевского процесс Овсянникова наталкивает на множество идей и размышлений, отличных от общепринятых. Появляется на страницах тетрадей и идея Подростка:

«Овсянниковъ, нажива, съ матерной кольбели, но въдь онъ мужикъ и нажива ему много значила. "Идея" Подростка»"29.

Овсянников отвечает за всю эпоху, что, по мнению Достоевского, несправедливо:

«Было множество дюль, которые могли возбудить жаръ гражданскій, но они прочли безсльдно, ихъ не хотпли даже замптить, но туть миліонб. Туть и не нахальство Овсяникова, жаръ гражданскій не обидится и нахальствомъ. А милліонъ, просто милліонь - вотъ въ чемъ бюда. Дескать милліонъ у Овсянникова, зачпмг [же] не у наст; Дави Овсянникова. <...> Но и въ самомг свирппствованіи противъ Овсянникова сльшалось не негодованіе противъ милліоновъ, а скорпе поклоненіе милліонамъ. Не придали-бы имъ въ такомъ случап, такой суевпрной важности»

«Поклонением миллионам» можно объяснить и такую нелюбовь многих к А. С. Суворину. Выходец из крестьян, он, по собственному признанию, до 14 лет читавший только Евангелие, к началу ХХ века издал около тысячи книг. Начиная свою журналистскую деятельность, он одалживал у приятеля пальто и деньги на билет в Петербург. Рожденный в избе, он стал известным фельетонистом, миллионером, издателем одной из самых читаемых в России газет, владельцем модного театра и огромного дома в Петербурге. Он был близок к правительству, имел большое влияние в обществе, но в своем дневнике признавался:

«Меня утешают тем, что я - власть, и что как власть, я должен терпеть. Чорт с ней, с властью! Чары ее я никогда не ощущал, негде было и некогда. Вечно занят, вечно в родном кружке. Лесть мне всегда была неприятна, ибо я никогда не думал о себе высоко. В это время нападок на меня сколько раз я думал, что попал на высоту не по праву, и сколько раз я плакал у себя в кабинете и спальне» ${ }^{31}$.

В начале 1870-х гг. отношение к Суворину было весьма противоречиво и у Достоевского. Ясно одно: Суворин интересен ему: 
«Суворинъ. Есть неискренность и декламація (ругая почти за каждый его фельетонь и ужасно любя читать его фельетонык)>» ${ }^{32}$;

«Воть этоть фельетонисть, еслибъ его подкупиль Овсяниковъ, взяль-бь онъ 50000 или не взяль. Можеть быть не взяль бы зная что это можеть профильтроваться открьться. Ну, а еслибъ такъ дать что ни за что-бы не от $\{\kappa\}$ рылось? Знаете что можеть быть не взяль-бы. Онб банбаронб, онб плуть, онъ Vibulenus, a $\{-\}$ пожалуй не взяль-бы. Значить кромп плутовства и актерства есть и благородство. Да, есть, и можеть гораздо больше чиммъ $\mathcal{M ь l}\left[\right.$ по]думаемъ» ${ }^{33}$.

Итак, Достоевский со свойственной ему эмпатией пытается понять и оправдать своего оппонента. Однако автор «Дневника писателя», по убеждениям славянофил, все еще считает Суворина западником:

«Между тпмг наши западники (Незнакомецб, Тургеневъ, Журналисть) и проч. Говорять и увпряють что стоять за народъ, и когда [народъ] говор[и] $\{я\} m ъ[ч m]\{u\} \mathcal{м б ~ ч т о ~ н а р о д б ~ н е ~ м о ж е т ь ~ б ы т ь ~ б е з б ~ т и ч н о с т и , ~ а ~ в ы - д е ~ о т в е р - ~}$ гаете всп наши народныя начала и смпетесь надъ ними, то они сердятся и говорять что они истинные народники, но съ тюмъ только чтобъ этоть народъ не имгль ничего своего. Но они ошибаются, ибо они не народники, а лишь аристократы и барчуки» ${ }^{34}$.

Вероятно, Достоевский не знает о социальном происхождении Суворина и потому ставит его в один ряд с Тургеневым. Для Достоевского не важно, к какому сословию принадлежит человек, - главное, каких взглядов он придерживается.

Действительно, для молодого Суворина Тургенев ближе и понятнее Достоевского. «Г. Достоевский не обладает тем талантом, который дает г. Тургеневу возможность схватывать современные явления, идеи, носящиеся в воздухе, и воплощать их в типы», - пишет он в 1867 г. ${ }^{35}$ Подобное мнение не было оригинальным в 1860-1870-е гг.: противостояние Достоевского и Тургенева занимало общественность как минимум до середины 1880-х. Суворин гораздо раньше выбрал для себя победителя в этой идейной дуэли, что легко проследить по публикациям «Нового времени» конца 1870 - начала 1900-х гг. Много позже в своем дневнике 65-летний Суворин напишет: «Достоевский возобладал над Тургеневым только после своей смерти» ${ }^{36}$.

Представляется интересной полемика Достоевского с Сувориным о спиритизме. В той же записной тетради за 1876 г. будущий автор «Братьев Карамазовых» обращает внимание на фельетон Незнакомца в № 357 «Биржевых ведомостей». Суворин выступает за христианское учение о бессмертии души и пишет, что в спиритизме «духи глупы». Достоевский в корне не согласен с этой мыслью:

«Незнакомецъ ошибается насчеть глупости ду́ховъ. Если это черти то ничего они не могли сдюлать хитрпе и [глубже] \{умнюе $\},$ какъ представиться 
сначала, въ первый періодъ Спиритизма глупияами и мелкими насмпшниками и обманщиками. И ужь конечно ими управляеть какой нибудь огромный нечистый духъ, страшной силь и поумнюе Мефистофеля <...>. Этоть главньй адскій духъ поглубже политикъ, чпмъ предполагаеть $I^{\frac{\mu b}{6}}$ Суворинб. <...> Явись черти съ откровеніями законовъ [и] природы и тайнъ Земныхъ и жизнь людей была бы украдена, а люди-бы, осыпанные благами, стали бы не тосковать а сначала вопить оть восторга: Кто подобень звюрю сему, онъ сводить огонь съ небеси. \{И неужели бь Незнакомець повприль? И туть о безотрадности ученія, конфисков. жизнь лись бы язвами и стали бы кусать языки свои въ мукахъ, увидя что жизнь у нихъ украдена за хлюбъ, за камни обращенные въ хлюбы, за возвпшеннья даромъ, \{безъ труда\} <...> Чгмъ гадка религіозная идея Спиритизма: кража вашей свободь. И они говорять что это сошествіе Духа Святаго! Никогда Богъ не позволить сдюлать такой ужасной вещи (шутки) съ человпкомъ. А между тюмъ сначала адепты были-бы навпрно, закричали бы и завопили, сказали бь: Конець матеріальнымъ нуждамъ, теперь лишь духовная жизнь! [Но] и кричали-бы, и были бы адепты, и какіе-бы умные люди это кричалибъ!! А и не зампттили-бы что духовной жизни ужъ больше нпть <...>. Хотябы изб мертвыхъ воскресъ и того не послушають. <...> Содержаніе преступника, скажуть, выйдеть лучше житья на волю и человпкъ поскорпе сдплаеть преступленіе чтобъ не жить въ иной адской жизни на воль?

Но то-то и есть, что лишеніе свободь - есть самое страшное истязаніе, которое почти не можеть перенесть человпкъ» ${ }^{37}$.

Возможно так, в мысленной полемике с Сувориным, рождается идея поэмы «Великий инквизитор».

В 1876 г. между Сувориным и Достоевским происходит постепенное сближение. Достоевский продолжает с интересом читать Суворина и в «Биржевых ведомостях», и в «Новом времени» (именно в этом году Суворин покупает свою знаменитую в будущем газету). В феврале этого года он записывает в тетради: «O mомъ, чmо ходиль къ Суворину» ${ }^{38}$, но не уточняет, что это была за встреча. Он отмечает фельетоны Суворина о Каткове, о Брюллове и Добролюбове, «о плюсовой литературе» (Достоевский ошибочно приписывает Суворину статью С. А. Венгерова в «Новом времени» «Литературные очерки. Общий взгляд на современную литературу» от 11 марта 1876 г.), о войне, о церковной собственности, о Европе и др.; размышляет «насчет Суворина и грубости нападок на него» ${ }^{39}$.

В начале января 1876 г. Суворин положительно отзывается о Достоевском в своем воскресном фельетоне, выделяя автора «Дневника писателя» из «согласного хора» либеральных литераторов. Он извещает читателей «Биржевых ведомостей» о предполагаемом издании «Дневника писателя», предлагая публике «поддержать это предприятие, если она ценит искреннюю мысль 
талантливого писателя, который пробует выбиться из-под издательских застав <...>. Я от всей души желаю Ф. М. Достоевскому успеха» ${ }^{40}$.

Достоевский не мог не оценить этого, тем более замечая начинающуюся перемену взглядов бывшего либерала Суворина. По поводу либерализма Суворин теперь писал:

«Во всех, решительно во всех газетах царствует какой-то сплошной либерализм, точно все нарочно сговорились, точно редакторы и издатели имели предварительное совещание, на котором протоколом постановлено - ничем не отличаться друг от друга. Бывало, встретишь какую-нибудь шипящую статейку, услышишь консервативный вой, который заставит встрепенуться, который кольнет прямо в сердце и поднимет нервы. Нынче - ничего подобного. Все ровно, все гладко, все достаточно либерально и достаточно бесплодно» ${ }^{41}$.

В первом же выпуске «Дневника писателя» Достоевский высказался:

«...Незнакомец, в одном из недавних фельетонов своих, говоря о том, как встретила пресса наша новый 1876 год, упоминает, между прочим, не без едкости, что всё обошлось достаточно либерально. Я рад, что он проявил тут едкость. Действительно, либерализм наш обратился в последнее время повсеместно - или в ремесло или в дурную привычку. То есть сама по себе это была бы вовсе не дурная привычка, но у нас всё это как-то так устроилось» (Д30; 22: 7).

Итак, Достоевский радуется перемене взглядов Суворина и уже в 1877 г. впервые пишет ему письмо:

«15 мая 77.

Милостивый государь Алексей Сергеевич,

Извините, что Вас обеспокоил и даже, кажется, Вас из-за меня разбудили. Я сам сплю до 2-х часов, когда работаю, и понимаю, как досадно, когда потревожат. <...>

Рассчитывал тоже, увидя Вас, не отказать себе в удовольствии заявить Вам о приятном впечатлении на меня по поводу собственно Ваших нескольких слов, на прошлой неделе, об Анне Карениной ${ }^{42}$. Хорошо то, что в наше смущенное время Вы провозглашаете важность литературного явления как общественного факта, не боясь величия войны и прочего. Этот новый взгляд в Вашей газете очень отраден. Ради Христа, не примите с моей стороны за похвалу и поощрение к дальнейшему. Я просто выражаю мое удовольствие, которое бы наверно выразил Вам, если б удалось встретиться, и лично <...>. Но извините, и примите как искреннее слово Вашего слуги,

Ф. Достоевского» (Д30; 29: 1 155-156). 
По этому письму заметно, как изменяется отношение Достоевского к Суворину: антагонизм постепенно перерастает в симпатию.

В 1877-1880 гг. Достоевский и Суворин нередко видятся на литературных вечерах, в гостях у общих знакомых (например, у С. И. Смирновой (Сазоновой $)^{43}$ ), участвуют в деятельности Общества любителей духовного просвещения. «Новое время» один за другим печатает положительные отзывы на «Дневник писателя» и уделяет немало внимания Достоевскому вообще. Уже в 1878 г. Достоевский приглашен к Суворину на празднование двухлетия газеты ${ }^{44}$. Дневник Суворина открывается знаменитым воспоминанием о том, как он был у Достоевского 20 февраля 1880 г., в день покушения И. О. Млодецкого на М. Т. Лорис-Меликова (эта запись подробно рассмотрена в книге «Последний год Достоевского» [Волгин, 2016: 33, 36-40]).

Однако, на наш взгляд, истинное сближение между писателями произошло лишь весной 1880 г. - благодаря не менее знаменитому «эпизоду с каймой». И хотя эта история весьма тщательно изучена ${ }^{45}$, кажется целесообразным упомянуть о ней вновь - в контексте того, как она явилась катализатором зарождающейся дружбы между Сувориным и Достоевским.

Примечательно, что среди огромного множества петербургских газет и журналов именно Суворин в «Новом времени» вступился за Достоевского, не поленившись «поднять» все альманахи «Современника» и скрупулезно отвечая на выпады оппонентов. Очевидно, что установить ложь П. В. Анненкова для Суворина важно уже не столько в контексте упомянутого «корпоративного» противостояния («Новое время» против «Вестника Европы»), сколько ради справедливости и защиты доброго имени Достоевского. Это видно и по переписке литераторов, касающейся данного вопроса. Широко известно письмо Суворина Достоевскому от 12 мая 1880 г., в котором он спрашивает: «Довольны ли Вы тюмъ, что написаль Буренинб о "каймю", или Вы желали бы, чтобъ объявить оть Вашего имени, что это ложь? <...> Дай Вамъ Богъ, поздоровпть» - и передает Достоевскому приглашение выступить в «Обществе любителей словесности» - почитать о Пушкине. «Если погдете, черкните мнгь два слова», - просит Суворин и даже предлагает взять для Достоевского билет на поезд, сообщая, что сам, возможно, не сможет приехать на мероприятие ${ }^{46}$. Из этого предложения становится ясно, что отношения между Сувориным и Достоевским - уже не столько деловые, сколько дружеские. Еще более подтверждает этот тезис ответное письмо Достоевского от 14 мая 1880 г.:

«Многоуважаемый Алексей Сергеевич,

Благодарю Вас за Ваше любезное письмо <...>. Известие, что Вы, может быmb, не поедете, мне очень неприятно: веселее было бы нам, петербургским гостям, быть там в более сплошной кучке. А потому: нельзя ли Вам постараться приехать? Постарайтесь-ка! <...> Насчет глупенькой “каймы” не знаю, что Вам сказать. Словами в "Нов<ом> времени" (о кайме) я конечно 
доволен. <...> Но если бы теперь Вы, например, как издатель газеты, поместили бы в ней всего пять строк в том смысле что: “Мы-де получили от Ф. М. Достоевского формальное заявление, что никогда ничего подобного рассказанному в “Вестн<ике> Европы” (насчет каймы) не было и не могло быть”, и проч. и проч. (формулировка по Вашему усмотрению), то я был бы Вам весьма за это благодарен. <...> Искренно Вас уважающий Ф. Достоевский» (Д30; 30 : 154-155).

Симпатия Достоевского к Суворину очевидна: он не только огорчен тем, что не увидит издателя «Нового времени» на Пушкинском празднике, но и обнаруживает серьезное доверие к нему относительно формулировки собственных слов по столь щепетильному вопросу. И это доверие не было обмануто: 18 мая 1880 г. Суворин, почти совсем не меняя авторской формулировки, печатает в «Новом времени» заявление: «Ф. М. Достоевский, находясь в Старой Руссе, где он лечится, просит нас заявить от его имени, что ничего подобного тому, что рассказано в “Вестнике Европы” П. В. Анненковым насчет каймы, не было и не могло быть...» ${ }^{47}$.

Достоевский, безусловно, оценил эту услугу. 3-4 июня 1880 г. он пишет жене из Москвы (куда он приехал выступать на открытии памятника Пушкину):

«Ровно в 10 часов воротился домой и застал у себя 2 карточки Суворина с надписанными строчками, что придет в 10 часов. 2 карточки были ошибкой (склеились), и я, подумав, что он был уже и во второй раз, но меня не застал, поехал в “Славянский базар” (очень недалеко от меня), где он стоит, и застал его с женою за чаем. Ужасно был рад. Он у “Любителей” за статьи свои на фербанте, как и Катков. Ему даже не дали билета на утренние заседания. У меня же был один билет (Варин, от которого она отказалась), и я предложил ему. Очень был рад. Уж даст он им знать потом. <..> Хотели прийти Григорович и Висковатов <...>. С заседания же они, в 10-м часу, укатили в “Эрмитаж” и ужасно просили, чтоб и я приехал, но я пошел к Суворину. Суворин, узнав, что мы завтра в Оружейную, упросил, чтоб и его с женой взяли, а затем стал просить, чтоб обедать вместе в "Москов<ском> трактире”, он с женой, я, Григорович и Висковатов, а затем чтоб поехать в “Эрмитаж”. Он, кажется, бедный, с женою скучает. На вечерних чтениях, где билеты за деньги, он, конечно, будет» (Д30; 30, $: 178-179)$.

По письмам к Анне Григорьевне Достоевской еще более заметно, как отношения между Достоевским и Сувориным перерастают в дружеские. В письме жене от 5 июня 1880 г. Достоевский рассказывает, как они с Сувориным «были в Кремле, в Оружейной палате, осматривали все древности <...>. Всё осмотрев, зашли в трактир Тестова закусить и остались обедать. <...> Затем по условию отправились в сад “Эрмитаж”. Там уже были Суворины, Григорович 
и проч. В саду же $<\ldots>$ сидел и всё время пил чай с Сувориными и с Бурениным...» (Д30; 30; : 179-180).

Свидетельства об этих встречах можно встретить и в воспоминаниях жены Суворина Анны Ивановны:

«...мы завтракали вместе с $Ф<$ едором $>\mathrm{M<ихайловичем}>$ у Тестова, ели расстегаи. Завтрак был интимный, была всё своя компания. Я была одна дама и сидела в средине стола и по правую руку мою кавалером моим был $\Phi<$ едор> М<ихайлович >. Нас было немного: я с мужем, Островский, Григорович, Максимов С. В., Горбунов и Берг Н. В. Завтрак шел оживленно. Конечно, разговоры шли о литературе и о политике» [Суворина: 8-9] (см. также: [Перлина: 299]).

«Пушкинская речь», сказанная Достоевским 6 июня 1880 г., как известно, произвела настоящий фурор. В дневнике Суворин вспоминал:

«Во время пушкинских дней в Москве, после его знаменитой речи, я пошел за сцену его поздравить. Он шел мне навстречу в зал и сказал радостно:

- “А что? Мы победили, победили! Женщины мне руку целуют!”.

Несколько девушек несли ему по залу в это время большой лавровый венок» ${ }^{48}$.

Интересен женский взгляд на ситуацию. Анна Ивановна так описывает этот эпизод:

«Окончилось чтение, все кинулись к выходу, к артистической комнате, навстречу Достоевскому, и тут произошло совершенно еще невиданное и не-ожиданное зрелище. Когда только вышел Достоевский, к нему буквально бросились девушки и вообще молодежь, толпою, некоторые прямо падали на колени перед ним, целовали ему руки; я такие сцены видела только после, с от<цом> Иоанном Кронштадтским, когда толпа буквально несла его. Наконец, несколько освободившись от восторженной толпы, он, поравнявшись с мужем и пожав ему руку, отвечал на приветствия Ал<ексея> Сергеевича, шепнув ему: “А, каково? Наша взяла!”. Алекс<ей> Серг<еевич> передавал это с восторгом, так как сам был всегда националистом и русским до глубины души. Я этого совершенно не понимала и удивлялась, что даже у таких громадных людей бывают слабости и такое тщеславие, но мой муж ответил, что это вовсе не тщеславие, а торжество их взглядов, их идей!» [Суворина: 8] (см. также: [Перлина: 299]).

Как видно, Суворин защищал Достоевского не только перед читателями русских газет, но даже в частных разговорах с собственной женой.

29 июня в «Новом времени» Суворин написал, что «Пушкинская речь» Достоевского «действительно явилась событием и похоронила под собою всех говоривших» и назвал ее «апофеозом праздника, высшей его точкой» ${ }^{49}$. 
В записной книжке 1880-1881 гг. Достоевский упомянул, что бывает на домашних литературных вечерах у Суворина. Писала об этом и Анна Ивановна:

«Приезжали к чаю к 9-ти часам, к ужину, к 12 приезжали обыкновенно из театра и артисты. <..> Любил посещать наши воскресенья и $Ф<$ едор> $\mathrm{M}<$ ихайлович $>$, часто оставался ужинать, чтобы послушать за ужином незабвенного и незаменимого моего дорогого кума Ив $<$ ана $>$ Фед<оровича $>$ Горбунова... Особенно любил $Ф<$ едор $>\mathrm{M}<$ ихайлович $>$ слушать роль генерала Дитятина и смеялся, как ребенок...» [Суворина: 10] (см. также: [Перлина: 300$])$.

Эти свидетельства прекрасно иллюстрируют, насколько тесными стали отношения Достоевского и Суворина к 1881 г.

Последняя их встреча произошла за десять дней до смерти Достоевского. Об этом Суворин написал в своих воспоминаниях «О покойном», опубликованных в «Новом времени»:

«Он приступил к печатанию своего “Дневника”. Срочная работа его волновала. Он говорил, что одна мысль о том, что к известному числу надо написать два листа - подрезывает ему крылья. Он не отдохнул еще после “Братьев Карамазовых", которые страшно его утомили, и он рассчитывал на лето. $<\ldots>$ Он много говорил в этот вечер, шутил <... Д. Достоевский обладал особенным свойством убеждать, когда дело касалось какого-нибудь излюбленного им предмета: что-то ласкающее, просящееся в душу, отворявшее ее всю звучало в его речах. Так он говорил и в этот раз» ${ }^{50}$.

28 января 1881 г. именно в «Новом времени» впервые появилось сообщение о болезни Достоевского:

«В сообщаемой сегодня программе пушкинского вечера читатели не найдут возвещенного прежде имени Ф. М. Достоевского. Он сильно занемог, вечером 26 января, и лежит в постели. Люди, еще так недавно попрекавшие его тем, что он слишком часто принимает овации на публичных чтениях, могут теперь успокоиться: публика услышит его не скоро. Лишь бы сохранилась для русского народа дорогая жизнь глубочайшего из его современных писателей, прямого преемника наших литературных гениев! $\aleph^{51}$.

В тот же вечер Достоевский скончался. Узнав о его смерти, Суворин одним из первых приехал на квартиру покойного, не веря в произошедшее. Той же ночью он написал проникновенную статью под заголовком «Кончина Ф. М. Достоевского», которая вышла в «Новом времени» без подписи утром 29 января:

«Мы видели его сейчас, около полуночи. Его только что обмыли и положили на стол. Он лежал как живой. Бледный, спокойный он точно спал <...>. Сердце разрывалось и слезы душили. Так неожиданна, так велика эта утрата, 
такого искреннего и глубокого мыслителя вырвала у нас безумная, безжалостная смерть» ${ }^{52}$.

В мистическом рассказе «Тень Достоевского», опубликованном 30 декабря 1894 г. в «Новом времени» ${ }^{53}$, Суворин вспоминал:

«Я поехал на его квартиру. Это было далеко за полночь. Не верилось в его смерть, или, вернее сказать, я чувствовал какое-то сомнение, смутное, странное, тревожное. Может быть, он не умер, и я застану его живым. Такое чувство мне много раз случалось испытывать после вести о смерти близких мне людей, и я думаю, что это инстинкт жизни и ненависть к смерти. Хочется отдалить на час, на четверть часа полную уверенность в смерти близкого мне человека» ${ }^{54}$.

Весь февраль смерть Достоевского была главной темой «Нового времени». Передовицы 30 и 31 января практически полностью посвящены некрологам и воспоминаниям о покойном. Кроме извещения «Кончина Достоевского», Суворин написал еще одну большую статью - «О покойном». В приписке к первой значилось: «Мы собрали между своими знакомыми 100 рублей на памятник на могиле Ф. М. Достоевского». Так Суворин положил начало большому сбору средств на возведение известного надгробия, созданного по проекту архитектора Х. К. Васильева и скульптора Н. А. Лаверецкого, установленного спустя два года после захоронения. 30 октября 1883 г. в газете была помещена обширная статья, посвященная открытию памятника, на котором «публики было до 800 человек, несмотря на отвратительную погоду, ветер, грязь и большой дождь».

$\mathrm{B}$ «Новом времени» подробно печатались отчеты о поступлениях средств и строительстве ремесленной школы, извещения о проведении литературных и музыкальных благотворительных вечеров в ее пользу и т. д. В хронике от 27 октября 1883 г. отмечено: «В день рождения Ф. М. Достоевского, 30 октября, одновременно последует открытие ему памятника в Александро-Невской лавре и открытие школы его имени в Старой Руссе - то и другое на средства, пожертвованные его почитателями: 3,241 руб. на памятник и 3,151 руб. на школу» 55 .

В 1882-1883 гг. из типографии Суворина выходит Полное собрание сочинений Ф. М. Достоевского в 12 томах, а в 1885-1886 гг. - его переиздание в шести томах под редакцией вдовы писателя (о чем также подробнейшим образом сообщается на страницах «Нового времени») (см. об издательской деятельности вдовы Достоевского: [Андрианова]). Кроме того, в газете регулярно объявляется подписка на эти собрания сочинений и другие книги Ф. М. Достоевского.

В дневнике от 28 сентября 1899 г. Суворин вспоминает:

«Я помню, какое впечатление произвела моя статья, без подписи, о смерти Достоевского. Я называл его “учителем”. Лорис-Меликов, прочитав ее, 
как рассказывал А. А. Скальковский, тотчас поехал к государю и выхлопотал пенсию вдове. Григорович приехал ко мне, говоря, что он плакал. Многие плакали. Я разжалобился. Вдова Достоевского понимала очень хорошо значение этой агитации. Она поцеловала мне руку» ${ }^{56}$.

В № 1770 «Нового времени» от 31 января 1881 г. сообщалось, что «сегодня А. Г. Достоевская, вдова Федора Михайловича, получила письмо от министра финансов, которым г. Абаза уведомил ее, что Государь Император, во внимание услуг, оказанных покойным ее мужем русской литературе, “в которой он занимает одно из самых почетных мест”, назначил ей нераздельно с детьми ежегодную пенсию в 2000 рублей» ${ }^{57}$.

К концу своей жизни Суворин особенно интересовался театром. Он не только стал заведовать театрально-критическим отделом в «Новом времени», но и в 1895 г. арендовал здание бывшего Апраксинского театра на Фонтанке, организовав свой собственный - так называемый «Театр Литературнохудожественного общества» (в народе носивший имя «Малый»).

Впервые читая роман «Идиот» в 1899 г., Суворин писал в дневнике:

«Эти дни читаю “Идиота” Достоевского. Никогда я этого романа не читал. Странный писатель! Мне кажется, что все его люди - от его нутра, его души и воображения. Таких людей он не видал, да таких, может, нет и не было. Были только, может, подобия им. Какую-то преступную душу, мрачную, таинственную, он изображает. Есть ли это русская душа? Много увлекательных страниц, много поистине драматических сцен. Все его романы в сценах. Он любит разговоры, тянет их бесконечно, и многие очень занимательны. Он говорил мне, когда я у него спросил однажды, почему он не писал драм? - “Белинский говорил, что драматический талант складывается сам собой, с молоду. Вот я и думал, что если я начал с романов и в них силен, то я не драматург”» ${ }^{58}$.

В одном из писем В. Д. Оболенской Достоевский несколько иначе изъясняет свое отношение к драме:

«Есть какая-то тайна искусства, по которой эпическая форма никогда не найдет себе соответствия в драматической. Я даже верю, что для разных форм искусства существуют и соответственные им ряды поэтических мыслей, так что одна мысль не может никогда быть выражена в другой, не соответствующей ей форме» ${ }^{59}$.

Речь в этой переписке идет о том, можно ли поставить на сцене «Преступление и наказание» (Оболенская обращается к писателю с просьбой «о дозволении» переработки романа в пьесу). До Оболенской аналогичную попытку дважды предпринял московский книготорговец А. С. Ушаков, но обе его инсценировки были отклонены цензурой. Лишь в октябре 1899 г. затея с переделкой знаменитого романа осуществляется, и впервые поставить его на сцене удается именно Суворину. 
Переделку текста представил драматург и тайный советник Я. А. ПлющикПлющевский под псевдонимом Дельер. В главной роли выступил актер П. Н. Орленев, которого Суворин считал «самым большим теперь дарованием из всех», кого он знал. О работе над этой пьесой хозяин Малого театра много пишет в своем дневнике. Например, 28 сентября 1899 г. Суворин отмечает, что переделка Плющика-Плющевского «мало удовлетворительна, не драматична. Конец можно было бы сделать гораздо эффектнее, напр., в больнице или на каторжных работах» ${ }^{60}$. Суворин явно недоволен теми изменениями, которые автор переделки вносит в роман Достоевского: «Относительно своего авторства вы очень ошибаетесь. Между вами и автором колоссальная разница» ${ }^{61}$, пишет Суворин Плющевскому в том же 1899 г. Отношения накалились до такой степени, что за день до премьеры спектакля Суворин грозился всё отменить и обещал через неделю нарезать, «как и он, сцен из "Преступления и наказания" и их давать» ${ }^{62}$. Однако премьера состоялась, и пьеса была разрешена к представлению в провинциях. В 1900 г. Орленев напечатал брошюру в 30000 экземпляров о «Преступлении и наказании» для гастролей в 30 городах России. «Орленев совершенно переделал свою роль по Достоевскому, отбросив все измышления Дельера, и вовсе откинул последнюю сцену, совсем никуда негодную. Со своим артистическим чутьем он сделал это изменение очень хорошо» ${ }^{63},-$ писал Суворин.

В 1907 г. сын издателя «Нового времени», М. А. Суворин, вместе с литературным критиком В. П. Бурениным поставил пьесу по роману Достоевского «Бесы», однако об этом нет ни одного упоминания в дневнике отца.

Таким образом, взаимоотношения Достоевского и Суворина сыграли важную роль как в жизни самого писателя, так и в деле сохранения памяти о нем. Эти отношения прошли большой путь от идейного антагонизма и корпоративного противостояния до искренней дружбы и взаимного уважения. Полемика с Сувориным послужила Достоевскому источником для множества публицистических текстов и идей будущих романов, а общение с Достоевским во многом способствовало коренным изменениям во взглядах Суворина. В своем дневнике издатель «Нового времени» признается в том, что Достоевский имел на него большое влияние. По словам А. В. Амфитеатрова, Суворин «любил Достоевского и был, по существу, достоевцем» ${ }^{64}$. Во многом благодаря Суворину и его «Новому времени» были собраны средства на памятник Достоевскому в Александро-Невской лавре и на школу имени Достоевского в Старой Руссе; в издательстве Суворина было дважды опубликовано Полное собрание сочинений Достоевского, и ни одна другая газета не писала о Достоевском так много и часто, как «Новое время». После смерти Достоевского Суворин неизменно поддерживал его вдову и дочь, принимая активное участие в деле сохранения наследия великого писателя, в том числе с помощью собственного театра. До самой своей смерти Суворин помнил и любил Достоевского, читая и перечитывая его произведения и продолжая размышлять над ними. 


\section{ПРИМЕЧАНИЯ}

* Исследование выполнено при финансовой поддержке РФФИ в рамках научного проекта № 18-012-90021 Достоевский.

1 [Суворин А. С.] Дневник Суворина А. С. М.; Пг., 1923. С. 207 (запись от 9 июня 1899 г.).

2 Известно множество разных псевдонимов Суворина: чаще всего он подписывался как «Незнакомец», в «Русском Инвалиде» - как «А. И-н», в «Русском Слове» - как «Землянский», в «Весельчаке» - как «Суровикин». Много статей напечатано в «Новом времени» без подписи. См.: [Масанов].

3 И-н А. Журнальные и библиографические заметки // Русский инвалид. 1864. 8 августа.

4 Во время печатания первых глав «Преступления и наказания» в Москве студентом А. М. Даниловым были убиты и ограблены отставной капитан ростовщик Попов и его служанка М. Нордман. В течение всего 1866 г. в газетах и журналах печатались сообщения о процессе Данилова, приговор был вынесен в феврале 1867 г.

5 И-н А. Журнальные и биографические заметки // Русский инвалид. 1867. 4 марта. № 63. Там же.

Там же.

1) А. С. Журналистика // Новое время. 1873. 16 января. - Отзыв на ноябрьский номер «Русского вестника» и роман «Бесы» Ф. Достоевского. Роман охарактеризован как «дикая болезненная фантасмагория высокого и когда-то светлого ума» и предлагается «поставить крест на этом писателе»;

2) А. С. Обозрение недельных газет // Новое время. 1873. 30 января. - Дается положительная оценка первых выпусков «Дневника писателя» и творчества Достоевского в целом; 3) А. С. Журналистика // Новое Время. 1873. 6 марта. - Ведется полемика со статьей Н. К. Михайловского о «Бесах», опубликованной в «Отечественных записках».

9 Тетради с вырезками хранятся в РГАЛИ (Ф. 459. Оп. 2. Ед. хр. 1099).

10 Там же.

11 Там же.

12 Достоевский Ф. М. Дневник писателя. Среда // Гражданин. 1873. 8 января. № 2. С. 32-36

13 Незнакомец. Недельные очерки и картинки // Санкт-Петербургские ведомости. 1873. 25 февраля.

14 Достоевский Ф. М. Учителю (Дневник писателя за 1873 г.) // Достоевский Ф. М. Полн. собр. соч.: в 30 т. Л., 1980. Т. 21. С. 113. Далее ссылки на это издание приводятся в тексте статьи с использованием сокращения Д30 и указанием тома, книги (нижний индекс), страницы в круглых скобках.

15 Незнакомец. Недельные очерки и картинки // Санкт-Петербургские ведомости. 1873. 15 июля.

16 РГАЛИ. Ф. 212.1.15. Л. 20.

17 Там же. Л. 22. Здесь и далее при цитировании автографа используются условные знаки: [] - для обозначения зачеркнутого текста, \{\} - для обозначения вписанного текста.

18 В 1866 г. Суворин (под псевдонимом А. Бобровский) опубликовал сборник «Всякие: очерки современной жизни», где высказал свое сочувствие Н. Г. Чернышевскому. За эту книгу Суворин был судим и приговорен к трем неделям содержания на гауптвахте; весь тираж сборника был изъят и сожжен.

19 РГАЛИ. Ф. 212.1.15. Л. 16.

20 Ленин В. И. Карьера // Правда. 1912. 18 августа.

21 Достоевский Ф. М. Записная тетрадь 1875-1876 гг. // Неизданный Достоевский. Записные 
книжки и тетради 1860-1881 гг. М., 1971. С. 382 (Литературное наследство; т. 83).

22 Суворин А. С. Письмо к Крамскому И. Н. // РГАЛИ. Ф. 783. Оп. 1. Ед. хр. 6.

23 Дневник Суворина А. С. С. 124 (запись от 13 октября 1896 г.).

24 Незнакомец. Недельные очерки и картинки // Биржевые ведомости. 1875. 7 декабря.

25 РГАЛИ. Ф. 212.1.15. Л. 8.

26 Незнакомец. Недельные очерки и картинки // Биржевые ведомости. 1875. 30 ноября, 14 декабря.

27 РГАЛИ. Ф. 212.1.15. Л. 25.

28 Там же. Л. 16 об.

29 Там же. Л. 19.

30 Там же. Л. 33, 33 об.

31 Дневник Суворина А. С. С. 198 (запись от 18 апреля 1899 г.).

32 РГАЛИ. Ф. 212.1.15. Л. 48.

33 Там же. Л. 28.

34 Там же. Л. 17-17 об.

35 И-н А. Журнальные и биографические заметки // Русский инвалид. 1867. 4 марта.

36 Дневник Суворина А. С. С. 212 (запись от 28 сентября 1899 г.).

37 РГАЛИ. Ф. 212.1.15. Л. 22, 22 об., 23 об., 24.

38 Там же. Л. 48.

39 Достоевский Ф. М. Записная тетрадь 1876-1877 гг. // Неизданный Достоевский. Записные книжки и тетради 1860-1881 гг. М., 1971. С. 560 (Литературное наследство; т. 83).

40 Недельные очерки и картинки // Биржевые ведомости. 1876. 4 января.

41 Там же.

42 Достоевский имеет в виду статью Суворина “"Анна Каренина” и ее общественное значение», опубликованную в «Новом времени» 13 мая 1877 г.

43 С. И. Смирнова - автор и сотрудница «Нового времени», всю свою жизнь вела дневники. В записи от 29 февраля 1880 г. значится: «Целый день гости! Мамаша, Виктор, Николай Васильевич, <..> Достоевский, Суворин» (цит. по: [Мостовская: 275]).

44 Запись от 2 марта 1878 г. из дневника С. И. Смирновой (Сазоновой): «Николай <Н. Ф. Сазонов> вечером у Суворина, где справляют двухлетие газеты. Много народу: Черняев, Достоевский, Данилевский, Кюи, Мясоедов и пр.» (цит. по: [Макарова, ч. 1]). Из того же дневника мы узнаем и о праздновании четырехлетия «Нового времени», во время которого Сазонова сидела между Достоевским и Сувориным, участвуя в их разговоре (см.: [Мостовская, 276]).

45 См., напр.: [Волгин, 2018: 493, 641-644, 646], [Волгин, 2016: 269-274], [Захаров, 1978: 87-89], [Захаров, 1985: 113-120].

46 Суворин А. С. Письмо к Достоевскому Ф. М. От 12 мая 1880 г. // Эпистолярное наследие Ф. М. Достоевского и его корреспондентов [Электронный ресурс]. Портал «PHILOLOG. RU». URL: http://philolog.petrsu.ru/fmdost/letters/suvor/otSuvorin12051880.pdf

47 Письмо в редакцию // Новое время. 1880. 18 мая.

48 Дневник Суворина А. С. С. 212-213 (запись от 28 сентября 1899 г.).

49 Незнакомец. Кое-что о Москве и провинции. Недельные очерки и картинки // Новое Время. 1880. 29 июня.

50 Незнакомец. О покойном // Новое время. 1881. 1 февраля. С. 2-3.

51 Без подписи. Пушкинский вечер // Новое время. 1881. 28 января. С. 1.

52 Без подписи. Кончина Ф. М. Достоевского // Новое время. 1881. 29 января. С. 1. 
53 Впоследствии рассказ был напечатан в типографии Суворина в 25 экземплярах для раздачи знакомым. Подробно текст рассказа разбирается в работе: [Битюгова].

54 В этом рассказе можно заметить перекличку с давней полемикой писателей о спиритизме (которую мы упоминали выше). Голова Достоевского является герою «Тени...» в качестве духа: «Дьяблере... дьявол... чёрт... таинственность... Отчего именно над письмом из Diableret я остановился?» - вопрошает он. «Мне становилось жутко, и я подчинялся тому, что называется паникой» - на наш взгляд, данный отрывок демонстрирует трансформацию суворинского восприятия «потустороннего»: в 1875 г. «духи глупы и смешны», в 1894 - таинственны и пугающи.

55 Хроника // Новое время. 1883. 27 октября.

56 Дневник Суворина А. С. С. 212 (запись от 28 сентября 1899 г.).

57 Чтобы понимать значение этой суммы, интересно обратить внимание на объявления, опубликованные в том же выпуске «Нового времени»: «хорошая квартира из пяти комнат, передней и кухни» сдавалась за 600 рублей в год; пуд ржаной муки стоил 11 рублей, а зарплата маляра составляла 331 рубль в год.

58 Дневник Суворина А. С. С. 209-210 (запись от 17 сентября 1899 г.).

59 Ф. М. Достоевский. Письмо В. Д. Оболенской. От 20 января 1872 г. (Достоевский Ф. М. Собр. соч.: в 15 т. Т. 15. С. 491).

60 Дневник Суворина А. С. С. 213 (запись от 28 сентября 1899 г.).

61 Там же. С. 210 (запись от 22 сентября 1899 г.).

62 Там же. С. 213 (запись от 4 октября 1899 г.).

63 Там же. С. 238 (запись от 16 апреля 1900 г.).

64 Амфитеатров А. В. Старик Суворин. 1934 [Электронный ресурс]. URL: http://az.lib.ru/a/ amfiteatrow_a_w/text_0514.shtml

\section{СПИСОК ЛИТЕРАТУРЫ}

1. Абросимова В. Н. Письма А. Г. и Л. Ф. Достоевских к А. С. Суворину // Летние чтения в Даровом: материалы междунар. научной конференции. - Коломна, 2006. - С. 85-86.

2. Азарина Л. Е. Литературная позиция А. С. Суворина: дис. ... канд. филол. наук. - М., 2008. - 203 c.

3. Битюгова И. А. К восприятию Достоевского на грани XIX-XX веков: (забытый фельетон А. С. Суворина) // Достоевский. Материалы и исследования. - СПб.: Наука, 2000. - T. 15. - C. 175-190.

4. Волгин И. Л. Последний год Достоевского. - 5-е изд. - М.: АСТ, 2016. - 780 с.

5. Волгин И. Л. Родиться в России. Достоевский: начало начал. - М.: Академический проект, 2018. - 749 с.

6. Захаров В. Н. Проблемы изучения Достоевского. - Петрозаводск: Изд-во ПетрГУ, 1978. - $112 \mathrm{c}$.

7. Захаров В. Н. По поводу одного мифа о Достоевском // Север. - 1985. - № 11. C. 113-120.

8. Макарова О. А. С. Суворин в дневниках С. И. Смирновой-Сазоновой. Часть $1 / /$ Новое литературное обозрение. — 2014. — № 130 (6) [Электронный pecypc]. — URL: https:// www.nlobooks.ru/magazines/novoe_literaturnoe_obozrenie/130_nlo_6_2014/article/11210/ (17.02.2019). 
9. Макарова О. А. С. Суворин в дневниках С. И. Смирновой-Сазоновой. Часть 2 // Новое литературное обозрение. - 2015. - № 131 (1) [Электронный ресурc]. — URL: https:// www.nlobooks.ru/magazines/novoe_literaturnoe_obozrenie/131_nlo_1_2015/article/11261/ (17.02.2019).

10. Масанов И. Ф. Словарь псевдонимов русских писателей, ученых и общественных деятелей: в 4 т. - М.: Изд-во Всесоюз. кн. палата, 1960. — Т. 4. - 558 с.

11. Мостовская Н. Н. Достоевский в дневниках С. И. Смирновой (Сазоновой) // Достоевский. Материалы и исследования. - Л.: Наука, 1980. - Т. 4. - С. 271-278.

12. Перлина Н. М. Достоевский в воспоминаниях А. И. Сувориной // Достоевский и его время: [сб. ст.]. - Л.: Наука, 1971. - С. 295-305.

13. Суворина А. И. Воспоминания о Ф. М. Достоевском / подгот. текста С. А. Кибальника, примеч. Б. Н. Тихомирова // Русские писатели 1860-х - 1880-х годов в забытых воспоминаниях, записных книжках и дневниках. - C. 1-18 [Электронный ресурс]. URL: http://www.lib.pushkinskijdom.ru/LinkClick.aspx?fileticket=C9nKFsz6iQ8\%3d\&tab $\mathrm{id}=10833$; http://www.lib.pushkinskijdom.ru/LinkClick.aspx?fileticket=1sdDN_ OuxX4\%3d\&tabid=10833 (18.01.2019).

14. Ярышева (Андрианова) И. С. А. Г. Достоевская как редактор и издатель // Достоевский и современность: материалы XXVI Международных Старорусских чтений 2011 года. - Великий Новгород, 2012. - С. 3-16.

\author{
Anastasia A. Proshchenko \\ (Moscow, Russian Federation) \\ anastessa@list.ru
}

\title{
F. M. Dostoevsky and A. S. Suvorin: Relationship History
}

Acknowledgments. The reported study was funded by RFBR, project number 18-012-90021 Dostoevsky.

Abstract. This article describes the evolution of the relationships between F. M. Dostoevsky and A. S. Suvorin. A particular attention is paid to the change of the views of the publisher of "Novoe vremya" on F. M. Dostoevsky's work and personality: their relationship came a difficult way from an ideological and political confrontation to mutual respect and friendship. The influence of A. S. Suvorin on the creative activity and the legacy of the writer is very extensive: it is not limited by the well-known memories from the diary of a media magnate, and goes far beyond his newspaper feuilletons. The publisher of "Novoye vremya" not only consistently supported Dostoevsky on the pages of his newspaper, but also took an active part in construction of a monument to the writer, creating Dostoevsky school in Staraya Russa, the preparation and publication of his Complete Works. A. S. Suvorin also supported Dostoevsky's family after his death, and in 1899 he first produced puting on a theatre stage of the "Crime and Punishment". Dostoevsky highly appreciated A. S. Suvorin and showed interest for his opinion: many ideas for future great works were born in the polemic with Neznakomets.

Keywords: A. S. Suvorin, journal "Novoe vremya", history of mutual relations

About the author: Proshchenko Anastasia A. - Teacher-researcher, Laboratory Assistant of the faculty of journalism, Lomonosov Moscow State University (ul. Mokhovaya 9/1, Moscow, 125009, Russian Federation)

Received: March 15, 2019

Date of publication: June 30, 2019

For citation: Proshchenko A. A. F. M. Dostoevsky and A. S. Suvorin: Relationship History. In: Neizvestnyy Dostoevskiy [The Unknown Dostoevsky], 2019, no. 2, pp. 149-170. DOI: 10.15393/ j10.art.2019.4061 (In Russ.) 


\section{REFERENCES}

1. Abrosimova V. N. Letters of Anna and Lyubov Dostoevskys to A. S. Suvorin. In: Letnie chteniya $v$ Darovom: materialy mezhdunarodnoy nauchnoy konferentsii [Summer Readings in Darovoe: Proceedings of the International Scientific Conference]. Kolomna, 2006, pp. 85-86. (In Russ.)

2. Azarina L. E. Literaturnaya pozitsiya A. S. Suvorina: dis. ... kand. filol. nauk [A Literary Position of A. S. Suvorin. PhD. philol. sci. diss.]. Moscow, 2008. 203 p. (In Russ.)

3. Bityugova I. A. On the Perception of Dostoevsky at the Turn of the 19th-20th Centuries: (the Forgotten Feuilleton of A. S. Suvorin). In: Dostoevskiy. Materialy i issledovaniya [Dostoevsky. Materials and Researches]. St. Petersburg, Nauka Publ., 2000, vol. 15, pp. 175-190. (In Russ.)

4. Volgin I. L. Posledniy god Dostoevskogo [The Last Year of Dostoevsky]. Moscow, AST Publ., 2016. 780 p. (In Russ.)

5. Volgin I. L. Rodit'sya v Rossii. Dostoevskiy: nachalo nachal [Born in Russia. Dostoevsky: Beginning]. Moscow, Akademicheskiy proekt Publ., 2018. 749 p. (In Russ.)

6. Zakharov V. N. Problemy izucheniya Dostoevskogo [The Problems of Studying Dostoevsky]. Petrozavodsk, Petrozavodsk State University Publ., 1978. 112 p. (In Russ.)

7. Zakharov V. N. About One Myth of Dostoevsky. In: Sever, 1985, no. 11, pp. 113-120. (In Russ.)

8. Makarova O. A. S. Suvorin in the Diaries of S. I. Smirnova-Sazonova. Part 1. In: New Literary Observer, 2014, no. 130 (6). Available at: https://www.nlobooks.ru/magazines/novoe_ literaturnoe_obozrenie/130_nlo_6_2014/article/11210/ (accessed on February 17, 2019). (In Russ.)

9. Makarova O. A. S. Suvorin in the Diaries of S. I. Smirnova-Sazonova. Part 2. In: New Literary Observer, 2015, no. 131 (1). Available at: https://www.nlobooks.ru/magazines/novoe_literaturnoe_ obozrenie/131_nlo_1_2015/article/11261/ (accessed on February 17, 2019). (In Russ.)

10. Masanov I. F. Slovar' psevdonimov russkikh pisateley, uchenykh i obshchestvennykh deyateley: $v 4$ tomakh [A Dictionary of Pseudonyms of Russian Writers, Scientists and Public Figures: in 4 Vols]. Moscow, Vsesoyuznaya knizhnaya palata Publ., 1960, vol. 4.558 p. (In Russ.)

11. Mostovskaya N. N. Dostoevsky in the Diary of S. I. Smirnova (Sazonova). In: Dostoevsky. Materialy i issledovaniya [Dostoevsky. Materials and Researches]. Leningrad, Nauka Publ., 1980, vol. 4, pp. 271-278. (In Russ.)

12. Perlina N. M. Dostoevsky in A. I. Suvorina’s Memoirs. In: Dostoevskiy i ego vremya [Dostoevsky and His Time]. Leningrad, Nauka Publ., 1971, pp. 295-305. (In Russ.)

13. Suvorina A. I. Memories of F. M. Dostoevsky. In: Russkie pisateli 1860-kh - 1880-kh godov $v$ zabytykh vospominaniyakh, zapisnykh knizhkakh i dnevnikakh [Russian Writers of the 1860s - 1880s in Forgotten Memories, Notebooks and Diaries]. Pp. 1-18. Available at: http:// www.lib.pushkinskijdom.ru/LinkClick.aspx?fileticket=C9nKFsz6iQ8\%3d\&tabid=10833; http://www.lib.pushkinskijdom.ru/LinkClick.aspx?fileticket=1sdDN_OuxX4\%3d\&tabid=10833 (accessed on January 18, 2019). (In Russ.)

14. Yarysheva (Andrianova) I. S. A. G. Dostoevskaya as an Editor and Publisher. In: Dostoevskiy i sovremennost': Materialy XXVI Mezhdunarodnykh Starorusskikh chteniy 2011 goda [Dostoevsky and Modernity: Proceedings of the 26th International Staraya Russa Conference of 2011]. Novgorod the Great, 2012, pp. 3-16. (In Russ.) 